\title{
Ultrasound examination of the pupil suggestive for carotid dissection
}

Figure 1 Ultrasonographical evaluation of the pupils
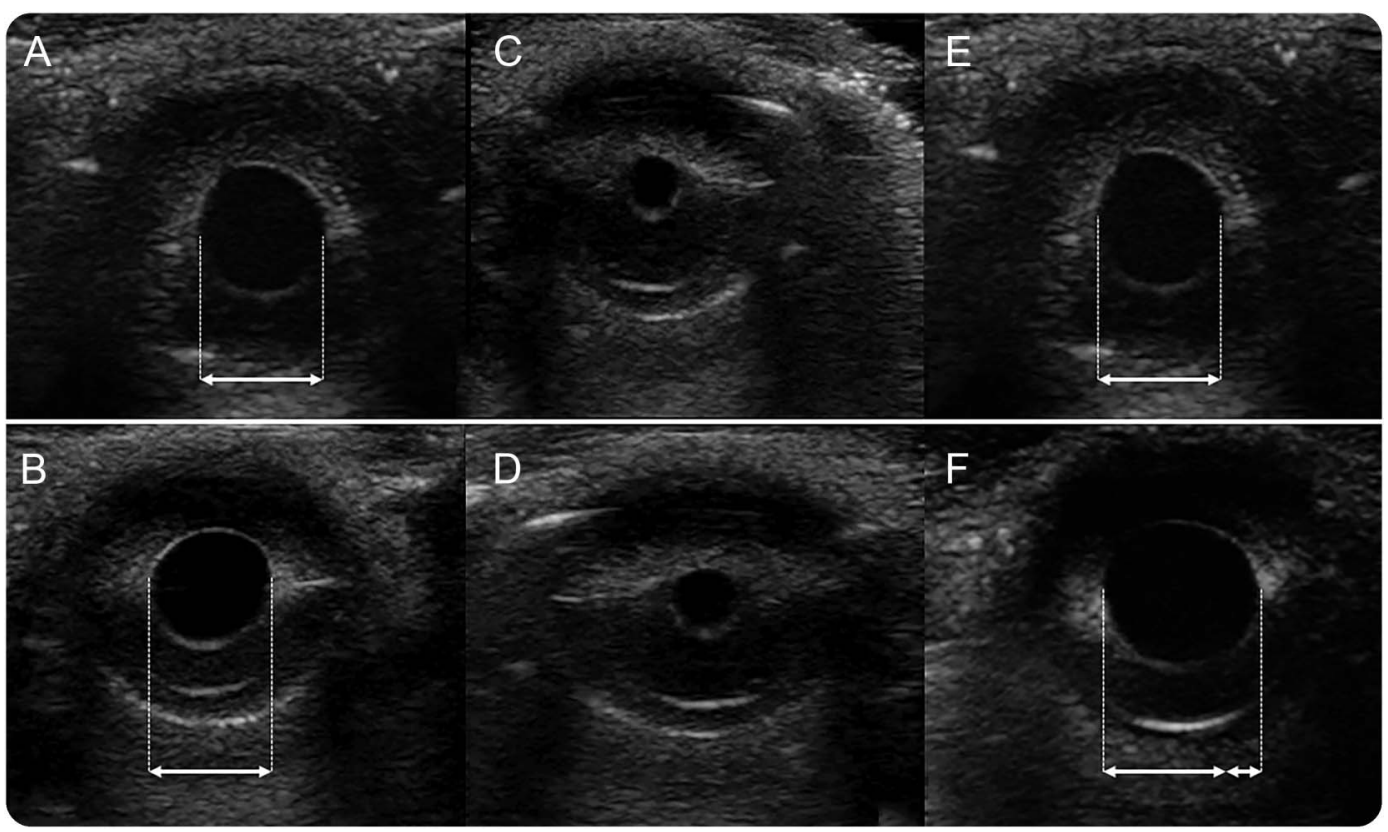

Ultrasound B-mode image of the pupillary diameter (A, B); normal pupillary reflex to light in right and left eyes (C, D); ciliospinal reflex in right $(E$, no reaction) and left eyes $(F$, normal mydriatic reaction, $\Delta$ dilation: $16 \%)$.

A 51-year-old man presented to our emergency department with persistent right cervical pain. Neurologic examination was unremarkable, and no anisocoria was reported. Using a linear ultrasound probe, the pupillary diameters were measured at rest, under direct/consensual light stimulus, and after elicitation of the ipsilateral ciliospinal reflex (CR), evoked by applying a painful stimulation (pinching) at the base of the neck on the trapezius muscle. ${ }^{1,2}$

Figure $2 \quad$ MRI of carotid dissection

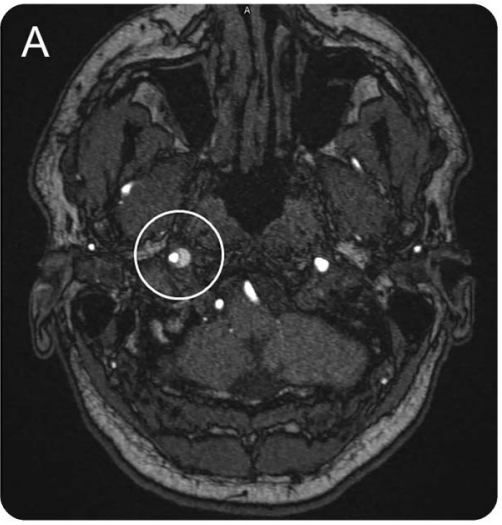

B

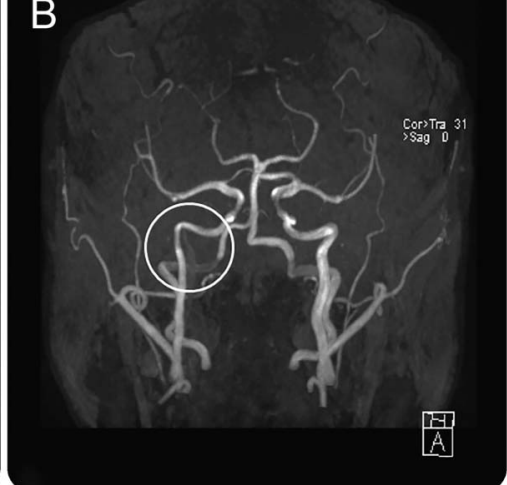

FAT/SAT MRI and magnetic resonance angiography with distal dissection of the right internal carotid artery $(\mathrm{A}, \mathrm{B})$. 
Although pupillary response to light was comparable on both sides (figure 1, A-D), mydriatic dilation after CR elicitation was completely absent on the right side (figure 1, E and F). FAT/SAT MRI showed a distal dissection of the right internal carotid artery (figure 2). Ultrasound examination helped to detect subtle pupillary dysfunction, not easily apparent to the clinician's eye.

Filippo Farina, MD, Cornelia Brunner, MD, Stephan J. Schreiber, MD, Anna Palmieri, MD, Walter Struhal, MD, Claudio Baracchini, MD, Milan R. Vosko, MD, PhD

From the Stroke Unit and Neurosonology Laboratory (F.F., A.P., C. Baracchini), Department of Neurological Sciences, University of Padua School of Medicine, Italy; Stroke Unit and Neurosonology Laboratory (C. Brunner, W.S., M.R.V.), Department of Neurology 2, Kepler Universitätsklinikum, Linz, Austria; and Department of Neurology (S.J.S.), Asklepios Clinic, Brandenburg an der Haven, Germany.

Author contributions: Filippo Farina has participated in the clinical management of the patient, performed the ultrasound examination, and involved in drafting and revising the manuscript. Cornelia Brunner has participated in the clinical management of the patient, gave technical assistance during ultrasound examination, and involved in drafting and revising the manuscript. Stephan J. Schreiber and Anna Palmieri were involved in drafting and revising the manuscript. Walter Struhal was involved in the methodology and revising the manuscript. Claudio Baracchini was involved in drafting and revising the manuscript. Milan R. Vosko has participated in the clinical management of the patient, gave methodical and technical assistance to the ultrasound examination, and involved in drafting and revising the manuscript.

Study funding: No targeted funding reported.

Disclosure: The authors report no disclosures relevant to the manuscript. Go to Neurology.org for full disclosures.

Correspondence to Dr. Vosko: milan.vosko@kepleruniklinikum.at

1. Sargsyan AE, Hamilton DR, Melton SL, Amponsah D, Marshall NE, Dulchavsky SA. Ultrasonic evaluation of pupillary light reflex. Crit Ultrasound J 2009;1:53-57.

2. McDougal DH, Gamlin PD. Autonomic control of the eye. Compr Physiol 2015;5:439-473.

\section{WriteClick ${ }^{\circledR}$ rapid online correspondence}

Have a comment on a recent Neurology ${ }^{\circledR}$ article you would like to share? Now it is easier and more convenient. Neurology.org has launched WriteClick on the home page and sidebars of each article to encourage remarks and debate among users.

WriteClick is restricted to comments about studies published in Neurology within the last eight weeks.

Learn more at Neurology.org/letters

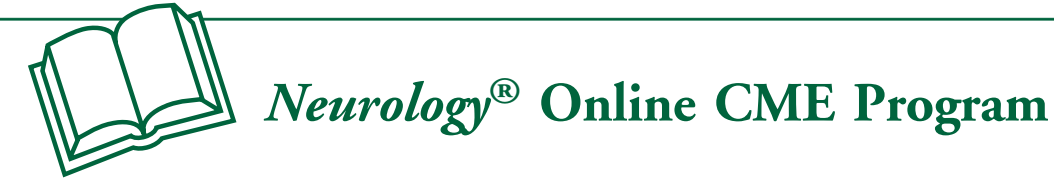

Earn CME while reading Neurology. This program is available only to online Neurology subscribers. Simply read the articles marked CME, go to Neurology.org, and click on CME. This will provide all of the information necessary to get started. The American Academy of Neurology (AAN) is accredited by the Accreditation Council for Continuing Medical Education (ACCME) to sponsor continuing medical education for physicians. Neurology is planned and produced in accordance with the ACCME Essentials. For more information, contact AAN Member Services at 800-879-1960. 


\section{Neurology}

\section{Ultrasound examination of the pupil suggestive for carotid dissection \\ Filippo Farina, Cornelia Brunner, Stephan J. Schreiber, et al. \\ Neurology 2017;89;973-974 \\ DOI 10.1212/WNL.0000000000004299}

This information is current as of August 28, 2017

\section{Updated Information \& Services}

\section{References}

Subspecialty Collections

Permissions \& Licensing

Reprints including high resolution figures, can be found at: http://n.neurology.org/content/89/9/973.full

This article cites 2 articles, 0 of which you can access for free at: http://n.neurology.org/content/89/9/973.full\#ref-list-1

This article, along with others on similar topics, appears in the following collection(s):

Carotid artery dissection

http://n.neurology.org/cgi/collection/carotid_artery_dissection Clinical neurology examination

http://n.neurology.org/cgi/collection/clinical_neurology_examination Pupils

http://n.neurology.org/cgi/collection/pupils

Ultrasound

http://n.neurology.org/cgi/collection/ultrasound

Information about reproducing this article in parts (figures,tables) or in its entirety can be found online at:

http://www.neurology.org/about/about_the_journal\#permissions

Information about ordering reprints can be found online:

http://n.neurology.org/subscribers/advertise

Neurology ${ }^{\circledR}$ is the official journal of the American Academy of Neurology. Published continuously since 1951 , it is now a weekly with 48 issues per year. Copyright @ 2017 American Academy of Neurology. All rights reserved. Print ISSN: 0028-3878. Online ISSN: 1526-632X.

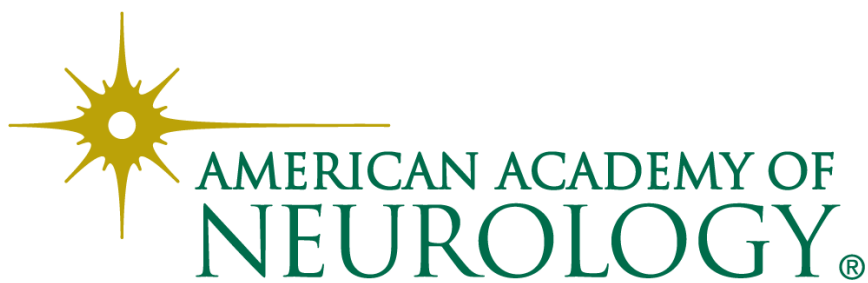

